\title{
Locoregional therapy of renal cancer
}

\author{
Tze Min Wah \\ From International Cancer Imaging Society (ICIS) 14th Annual Teaching Course \\ Heidelberg, Germany. 9-11 October 2014
}

This lecture aims to provide an overview of renal cell carcinoma (RCC) and insights into this rapidly evolving treatment - image guided thermal ablative (IGA) therapy. RCC is the commonest kidney cancer and the detection of RCC has increased over the past decade. There are over 8000 and 50,000 new cases/year in the UK and USA respectively $[1,2]$. The increased detection is due to wider usage of radiology (e.g. ultrasound or computed tomography) and this usually results in the detection of smaller RCC with earlier stage disease $[3,4]$. In addition, this is also related to the rise in incidence in the general population as a result of smoking and obesity [5-7].

The historical classical clinical triad where patients presented with flank pain, abdominal mass and haematuria is now a rarity and nowadays the majority of the incidentally detected RCCs are smaller and at an earlier stage $-\mathrm{T} 1$ stage. However, historical data has suggested that $60 \%$ of these small incidentally detected tumours will grow gradually over a period of time [8]. Therefore, there remains a clinical risk with adopting a 'watchful waiting' approach for younger patients as these tumours may become symptomatic or metastasize [9].

Open radical nephrectomy ( $\mathrm{RN})$ was the gold standard treatment for RCC since it was introduced in 1869 and Robson et al had popularized this treatment over the last 50 years [10].Over the past 10 years, laparoscopic $R N$ is becoming the standard of care with better cosmetic results and shorter recovery time [11]. More recently for locally confined (T1 disease) RCC treatment with nephron sparing surgery (NSS) e.g. open/ laparoscopic PN has demonstrated similar oncological durability to that of the gold standard RN [12,13]. RN is now largely considered an overtreatment for T1a $(<4 \mathrm{~cm})$ RCC because it is associated with greater nephron loss and earlier onset of chronic

\footnotetext{
Correspondence: Tze.Wah@leedsth.nhs.uk

Department of Diagnostic and Interventional Radiology, Institute of Oncology, St. James' University Hospital, Leeds Teaching Hospitals Trust,
} Beckett Street, Leeds, LS9 7TF, UK kidney disease and also associated with increased cardiovascular events after RN [14,15].

Therefore, the current consensus is that RCC at stage T1a $(<4 \mathrm{~cm})$, should be treated with minimally invasive techniques in order to preserve renal function. Nephron sparing surgery (NSS) with either laparoscopic/open PN is advised whenever it is deemed technically possible [16]. Although, the NSS has similar recurrence free and long term survival outcomes as those with RN, NSS remains technically challenging and associated with significant morbidity even in expert hands $[14,15]$.

Given the surgical challenges and the quest to preserve renal function, IGA treatment of the smaller RCC with radiofrequency ablation (RFA), cryoablation (CRYO) and microwave (MWA) has evolved rapidly over the last decade. Today, IGA of RCC has proven to be a safe and effective treatment option and good oncological outcome data is emerging for RFA [17-22] and CRYO [23,24]. In the hands of an experienced interventional oncologist, the primary technical success is now approaching $>95 \%$ for both IGA with RFA and CRYO. As RFA was introduced earlier, the emerging larger RFA series have demonstrated cancer specific survival of $97-100 \%$ with a follow up of 61-78 months [17-22].

\section{Acknowledgements}

would to acknowledge my interventional oncology $(\mathrm{IO})$ team (radiologistslead radiographer (Mike Gallagher) and lead administrative coordinator (Janette Bambrook) and collaborative clinicians and allied healthcare staff at Leeds Teaching Hospital Trust as the success of this programme is very

\section{Published: 9 October 2014}

\section{References}

Statistics Of N: Cancer Statistics registrations: Registrations of cancer diagnosed in 2008, England. Office for National Statistics, National Statistics London; $2010 \mathrm{MB} 1$.

2. Jemal A, Siegel R, Ward E, Hao Y, Xu J, Thun MJ: Cancer statistics, 2009. CA Cancer J Clin 2009, 59(4):225-249. 
3. Patard JJ, Rodriguez A, Rioux-Leclercq N, Guille F, Lobel B: Prognostic significance of the mode of detection in renal tumours. BJU Int 2002, 90(4):358-363.

4. Tsui KH, Shvarts O, Smith RB, Figlin RA, deKernion JB, Belldegrun A: Prognostic indicators for renal cell carcinoma: a multivariate analysis of 643 patients using the revised 1997 TNM staging criteria. J Urol 2000, 163(4):1090-1095.

5. Jayson M, Sanders $H$ : Increased incidence of serendipitously discovered renal cell carcinoma. Urology 1998, 51(2):203-205.

6. Hollingsworth JM, Miller DC, Daignault S, Hollenbeck BK: Rising incidence of small renal masses: a need to reassess treatment effect. J Natl Cancer Inst 2006, 98(18):1331-1334

7. Nguyen MM, Gill IS, Ellison LM: The evolving presentation of renal carcinoma in the United States: trends from the Surveillance, Epidemiology, and End Results program. J Urol 2006, 176(6 Pt 1):2397-2400, discussion 2400.

8. Kato M, Suzuki T, Suzuki Y, Terasawa Y, Sasano H, Arai Y: Natural history of small renal cell carcinoma: evaluation of growth rate, histological grade, cell proliferation and apoptosis. J Urol 2004, 172(3):863-866.

9. Abouassaly R, Lane BR, Novick AC: Active surveillance of renal masses in elderly patients. J Urol 2008, 180(2):505-508, discussion 508-509.

10. Robson CJ, Churchill BM, Anderson W: The results of radical nephrectomy for renal cell carcinoma. J Urol 1969, 101(3):297-301.

11. NICE: Guidance on Cancer Services. Improving Outcome in Urological Cancers. 2002.

12. Hemal AK, Kumar A, Kumar R, Wadhwa P, Seth A, Gupta NP: Laparoscopic versus open radical nephrectomy for large renal tumors: a long-term prospective comparison. J Urol 2007, 177(3):862-866.

13. Gill IS, Kavoussi LR, Lane BR, Blute ML, Babineau D, Colombo JR Jr., Frank I, Permpongkosol S, Weight CJ, Kaouk JH, Kattan MW, Novick AC: Comparison of 1,800 laparoscopic and open partial nephrectomies for single renal tumors. J Urol 2007, 178(1):41-46.

14. Huang WC, Elkin EB, Levey AS, Jang TL, Russo P: Partial nephrectomy versus radical nephrectomy in patients with small renal tumors-is there a difference in mortality and cardiovascular outcomes? J Urol 2009, 181(1):55-61, discussion 61-52.

15. Huang WC, Levey AS, Serio AM, Snyder M, Vickers AJ, Raj GV, Scardino PT, Russo P: Chronic kidney disease after nephrectomy in patients with renal cortical tumours: a retrospective cohort study. Lancet Oncol 2006, 7(9):735-740.

16. Ljungberg B, Cowan NC, Hanbury DC, Hora M, Kuczyk MA, Merseburger AS, Patard JJ, Mulders PF, SinesCU IC: EAU guidelines on renal cell carcinoma: the 2010 update. Eur Urol 2010, 58(3):398-406.

17. Levinson AW, Su LM, Agarwal D, Sroka M, Jarrett TW, Kavoussi LR, Solomon SB: Long-term oncological and overall outcomes of percutaneous radio frequency ablation in high risk surgical patients with a solitary small renal mass. J Urol 2008, 180(2):499-504, discussion 504.

18. Ferakis N, Bouropoulos C, Granitsas T, Mylona S, Poulias I: Long-term results after computed-tomography-guided percutaneous radiofrequency ablation for small renal tumors. J Endourol 2010, 24(12):1909-1913.

19. Zagoria RJ, Pettus JA, Rogers M, Werle DM, Childs D, Leyendecker JR: Long-term outcomes after percutaneous radiofrequency ablation for renal cell carcinoma. Urology 2011, 77(6):1393-1397.

20. Olweny EO, Park SK, Tan YK, Best SL, Trimmer C, Cadeddu JA: Radiofrequency ablation versus partial nephrectomy in patients with solitary clinical T1a renal cell carcinoma: comparable oncologic outcomes at a minimum of 5 years of follow-up. Eur Urol 2012, 61(6):1156-1161

21. Wah TM, Irving HC, Gregory W, Cartledge J, Joyce AD, Selby PJ: Radiofrequency ablation (RFA) of renal cell carcinoma (RCC): experience in 200 tumours. BJU Int 2014, 113(3):416-428.

22. Psutka SP, Feldman AS, McDougal WS, McGovern FJ, Mueller P, Gervais DA: Long-term oncologic outcomes after radiofrequency ablation for T1 renal cell carcinoma. Eur Urol 2013, 63(3):486-492.

23. Buy X, Lang H, Garnon J, Sauleau E, Roy C, Gangi A: Percutaneous renal cryoablation: prospective experience treating 120 consecutive tumors. AJR Am J Roentgenol 2013, 201(6):1353-1361.

24. Breen DJ, Bryant TJ, Abbas A, Shepherd B, McGill N, Anderson JA, Lockyer RC, Hayes MC, George SL: Percutaneous cryoablation of renal tumours: outcomes from 171 tumours in 147 patients. BJU Int 2013, 112(6):758-765.
doi:10.1186/1470-7330-14-S1-O20

Cite this article as: Wah: Locoregional therapy of renal cancer. Cancer Imaging 2014 14(Suppl 1):O20.

\section{Submit your next manuscript to BioMed Central and take full advantage of:}

- Convenient online submission

- Thorough peer review

- No space constraints or color figure charges

- Immediate publication on acceptance

- Inclusion in PubMed, CAS, Scopus and Google Scholar

- Research which is freely available for redistribution
C Biomed Central 